\title{
ORIENTALISM IN THE TALE OF GENJI'S TRANSLATIONS AS WORLD LITERATURE
}

\author{
Dewi Christa Kobis \\ dechriskobis@gmail..com \\ STMIK Multicom Bolaang Mongondow \\ Kotamobagu - Sulawesi Utara
}

\begin{abstract}
This paper is to discuss the "Orientalism" in The Tale of Genji as world literature through the translations of The Tale of Genji that had been translated into English by the Westerns. The popularity of The Tale of Genji cannot be separated from the important role of the translation. The English translations of The Tale of Genji had become a tool for the people surround the World to enjoy reading The Tale of Genji although they cannot speak or read Japanese. We cannot take lightly the role of translation. Regarding to the translation issue, it is also important to know closely about the translators' perspective towards The Tale of Genji. Since the major translators of The Tale of Genji are Western, it is imperative to know Westerns' perspectives towards Easterns since The Tale of Genji came from Asian. With the purpose to resolve this case, the analysis of this paper uses Orientalism as its theoretical concept in examining the Westerns' perspective towards The Tale of Genji through the translation. This paper also examines how the translations of The Tale of Genji could be easily received as the world literature.
\end{abstract}

Key Words: Genji, World Literature, Translation, Orientalism.

\section{INTRODUCTION}

\section{Why the Tale of Genji?}

Among the famous novels or other literary products which have been claimed to be world literature, The Tale of Genji is one of world literatures which were originally from Asian which is still interesting to be analyzed. The Tale of Genji is written in the early years of the 11th century, around the climax of the Heian period. In investigating the world literature, The Tale of Genji is worthy to be investigated because it is a Japanese novel which has been clarified to be the first world literature which had been written by a Japanese woman and caught much of international attentions (Arntzen 25). Besides being called as the world's first novel, The Tale of Genji is also being called as the first modern novel, the first psychological novel or the first novel which is still considered to be a classic. Particularly, the novel also illustrates a unique depiction of the livelihoods of high courtiers during the Heian period and every aspects and conflicts in The Tale of
Genji successfully made this novel interesting to be read (Ingram 12). Thus, The Tale of Genji is worthy to be examined.

\section{Why Translation?}

Since The Tale of Genji as the Asian novel was declared as the first novel in the world rather than Western novel, it really brings up curiosity to know the reasons behind this case. The Tale of Genji became the world literature after it had been translated into English. The first English translation of The Tale of Genji by Arthur Waley has been published in 1933 and it was the first translation by a Westerner that might lead other English two translations by Edward Seidensticker (1977), and Royall Tyler (2001). Actually there was a first English translation by a Japanese man named Kencho Suematsu (1887), but The Tale of Genji finally found its essential position as the world literature when it has been translated by Waley in 1933. deGruchy states that English translation of The Tale of Genji captivated the hearts and minds of readers for 
generations ${ }^{1}$. It means translation also plays an important role in making The Tale of Genji as world literature.

\section{Why Orientalism?}

It is necessary to know the Western's opinions regarding to the existence of The Tale of Genji that made the translators translate The Tale of Genji on the ways like they translate on the novel's translation. The perspectives from the Western are vital to be interpreted, so that we could know how the Western percept the Japanese culture through The Tale of Genji. The use of literary criticism which is called "Orientalism" is fit in discussing this matter. Since Orientalism is "primarily a term used for the imitation or depiction of aspects of Eastern cultures in the West by writers, designers and artists" (Said 1). It means we can know more about the roots of the Western's perspectives that produced the English translations of The Tale of Genji which are success to bring The Tale of Genji as one of the world's literature treasure. By using Orientalism, we can also know that if there are factors that had been influenced by the Western into the translation so the readers who are not from the Asian can enjoy the story in The Tale of Genji or not. Thus, further analysis about The Tale of Genji as world literature by the support of translation through the lens of Orientalism is needed to be examined more.

Based on the several clarifications above, we found out the reasons why this paper is necessary to be conducted. We need to know how the Westerns depicted Asian through The Tale of Genji, and we could find the answers by using Orientalism as the medium in analyzing The Tale of Genji. We could also examine the reasons why The Tale of Genji has been affirmed as the world literature. This will make us know more about the characteristics of world literature. Therefore, we can distinguish which

1 John Walter deGruchy. Orienting Arthur Waley: Japonism, Orientalism, and the Creation of Japanese Literature in English. (University of Hawaii Press, 2003) 1. literary product that can be called world literature or not.

\section{DISCUSSION}

1. RQ1: How is The Tale of Genji portrayed through Orientalism in the part of translation?

\section{a. Orientalism}

Since Edward Said published his book entitled "Orientalism", many scholars use this term in investigating the Orients. By using "Orientalism", we could analyze more about the Westerns' perspectives toward the Orients. Said proposed that:

The Orient is an integral part of European material civilization and culture. Orientalism expresses and represents that part culturally and even ideologically as a mode of discourse with supporting institutions, vocabulary, scholarship, imagery, doctrines, even colonial bureaucracies and colonial styles. In contrast, the American understanding of the Orient will seem considerably less dense, although our recent Japanese, Korean, and Indochinese adventures ought now to be creating a more sober, more realistic "Oriental" awareness. Moreover, the vastly expanded American political and economic role in the Near East (the Middle East) makes great claims on our understanding of that Orient. (19)

We figured out that when the Westerns' perspectives about the Orients were created through the colonization. Every aspect whether it is politic, education, economic, culture, or religion can be entered by the Westerns in conducting perspectives toward the Orients. So when the Westerns get in touch with the Orients, it helps them to understand the Orients more. 


\section{b. Orientalism in the Tale of Genji}

\section{The Tale of Genji in the Eyes of the Western Translators}

Individually, the researcher of this research tried to analyze the perspectives from the two translators of The Tale of Genji which have become the main two translations were used by the many shcolars in analyzing The Tale of Genji. They are the translations from Arthur Waley (1933) and from Edward Seidensticker (1977). The researcher used one chapter of the novel entitled "Yugao" (Waley) or "Evening Faces" (Seidensticker) as media to compare these two translators' perspectives toward The Tale of Genji in their translation. The general comparisons between the two translators that the researcher found are:

1. Waley $\rightarrow$ Put the conversations or poems directly into texts or dialogue.

Seidensticker $\rightarrow$ Segregate the conversations or poems from the passage or paragraph.

2. Waley $\rightarrow$ Use third singular person / pseudo name / another name to address a person, a place, or an activity. (eg. P.106, 110-113, 116, 119-122,126,129-130,134)

Seidensticker $\rightarrow$ Directly use the name of the person, place, or activity.

3. Waley $\rightarrow$ Try to translate every word / statement / symbol into English.

Seidensticker $\rightarrow$ Still managed to use Japanese word in the translation.

4. Waley $\rightarrow$ Try to explain more about the conversation and condition in the story.

Seidensticker $\rightarrow$ Try to explain or describe more about appearance.

\section{Examples of the Analysis on the Translation: \\ Example 1:}

$>$ Waley $\rightarrow$ "It was at the time when he was secretly visiting the lady of the Sixth Ward. One day on his way back from the palace he thought that he would call upon his foster mother who, having for a long while been very ill, had become a nun. She lived in the Fifth Ward. After many inquiries he managed to find the house; but the front gate was locked and he could not drive in. He sent one of his servant for Koremitsu, his foster nurse's son, and while he was waiting began to examine the rather wretched-looking by-street." p.106.

$>$ Seidensticker $\rightarrow$ "On his way from court to pay one of his calls at Rokujo, Genji stopped to inquire after his old nurse, Koremitsu's mother, at her house in Gojo. Gravely ill, she had become a nun. The carriage entrance was closed. He sent for Koremitsu and while he was waiting looked up and down the dirty, cluttered street." p.57.

Based on examples above, we found out that Waley prefered to use the pseudo name (The lady of the Sixth Ward) rather than the original name in the novel while Seidensticker prefered to use the Japanese name directly (Rokujo). Waley was also not consistent in translating each word. For example, at the first he translated "his foster mother", and then turned into "his foster nurse". Seidensticker just used "his old nurse" in translating the words. Regarding to the closeness in the relationship, "foster mother" is closer rather than "foster nurse". Waley looked like want to show the relationship between Genji and his foster mother. Although she was just the lady who took care of him, but Genji treated her as his mother. Regarding to the words "been very ill" and "gravely ill", Seidensticker described that Genji's foster mother was not just ill but her ill was very serious. Seidensticker's description about the health condition seemed to be more complex.

\section{Example 2:}

Waley $\rightarrow$ "The house next door was fenced with a new paling, above which at one place were four or five panels of open trelliswork, screened by blinds which were very white and bare. Through chinks in these blinds a 
number of foreheads could be seen. They seemed to belong to a group of ladies who must be peeping with interest into the street below. At first he thought they had merely peeped out as they passed; but he soon realized that if they were standing on the floor they must be giants. No, evidently they had taken the trouble to climb onto some table or bed; which was surely rather odd! " p.106-107.

$>$ Seidensticker $\rightarrow$ "Beside the nurse's house was a new fence of plaited cypress. The four or five narrow shutters above had been raised, and new blinds, white and clean, hung in the apertures. He caught outlines of pretty foreheads beyond. He would have judged, as they moved about, that they belonged to rather tall women.

What short of women might they be?" p.57.

Based on the examples of the translation above, we found out Seidensticker was more specific in describing the place or situation. Waley just translated "the house next door", but Seidensticker translated "beside the nurse's house", so the readers might understand clearly where the exact place that had been mentioned in the story. We can also see that Seidensticker focused on the appearance by looking at his words "pretty foreheads" while Waley just translated "number of foreheads". Seidensticker also put a statement of the question like "what short of women might they be?" Maybe it aimed to make the readers have imaginations toward the story.

\section{Example 3:}

Waley $\rightarrow$ "The man entered at the half-opened door, and had begun to pluck the flowers, when a little girl in a long yellow tunic came through a quite genteel sliding door, and holding out toward Genji's servant a white fan heavily perfumed with incense, she said to him, "Would you like something to put them on? I am afraid you have chosen a wretched-looking bunch," and she handed him the fan." p.107.

$>$ Seidensticer $\rightarrow$ "The man went inside the raised gate and broke off a flower. A pretty girl in long. unlined yellow trousers of raw silk came out through a door that seemed too good for the surroundings. Beckoning to the. She handed him a heavily scented white fan. "Put it on this. It isn't much of a fan, but then it isn't much of a flower.." p.57.

Based on this example, we got
another addition example that
Seidensticker was really into the explantion of the appearance. While Waley just translated "a little girl with yellow tunic", Seidensticker translated "a pretty girl in long, unlined yellow trousers of raw silk". Seidensticker was not only translating about the beauty, but also the description about the cloth more than Waley. But regarding to the politeness, Waley seemed to translate the words in more polite way like on the sentence "Would you like something to put them on" while Seidensticker translated "Put it on this" which was a sentence of a command.

\section{Example 4:}

$>$ Waley $\rightarrow$ "How beautiful he looked standing there, she thought." p.112.

$>$ Seidensticker $\rightarrow$ " $\mathrm{He}$ was an incomparably handsome figure as he paused to admire the profusion of flowers below the veranda." p.63.

$>$ Waley $\rightarrow$ "She wore a light green skirt exquisitely matched to the season and place; it was so hung as to show to great advantage the grace and suppleness of her stride. p.112.

$>$ Seidensticker $\rightarrow$ "In an aster robe that matched the season pleasantly and a gossamer train worn with clean elegance, she was a pretty, graceful woman." p.63. 
On this example, we can see that Seidensticker described the appearance or the beauty of the character in more aggressive way, like when he translated "he was an incomparably handsome figure" while Waley just translated "how beautiful he looked". Seidensticker even translated "in an aster robe" while Waley just translated "a light green skirt". Waley focused on the color of the robe but Seidensticker focused on the ornament or images on the robe.

Based on the examples and analysis that have been clarified above, we found out that both Waley and Seidensticker tried to translate The Tale of Genji well based on their knowledge in the Japanese. Waley's translations might have several lacks so Seidensticker came to translate The Tale of Genji in his way.

\section{The Tale of Genji in the Eyes of the Readers of the Translation}

On her fourth volume essay (19251928), Virgina Woolf analyzed the English translation of The Tale of Genji which was translated by Arthur Waley. She proposed that on Waley's translation, Genji seemed to be "in the contemplation of man's nature; how passionately he desires things that are denied; how is longing for a life of tender intimacy is always thwarted; how the grotesque and the fantastic excite him beyond the simple and straightforward; how beautiful the falling snow is, and how, as he watches it, he longs more than ever for someone to share his solitary joy" (256). Woolf seemed to describe Genji as someone who missed someone to erase his loneliness, and everything that Genji needs to fulfill his own desire is to get the intimacy.

Woolf also commented that "the Lady Murasaki (the author) lived, indeed, in one of those seasons which are most propitious for the artist, and, in particular, for an artist of her own sex. The accent of life did not fall upon war; the interests of men did not centre upon politics" (256257). This is an interesting finding from Woolf. From this statement, we know that on The Tale of Genji which is an oldest novel from Japan that had been written in 11th century when most of men focused on politic matter and war, The Tale of Genji focuses on the prince's interests toward women.

Another attractive matter is also elucidated by Woolf in her essay. She focused on the explanation of the architecture in The Tale of Genji. Woolf states that "something of her (Lady Murasaki) charm for us is doubtless accidental. It lies in the fact that when she speaks of houses such as you may see anywhere we at once conjure up something graceful, fantastic, decorated with cranes and chrysanthemums" (266). Woolf seemed to admire the explanation about the places in The Tale of Genji that has been written by Lady Murasaki through Waley's translation.

Woolf also mentioned about Lady Murasaki's artistic quality in creating imaginative characters from the women in The Tale of Genji. Woolf states that "Lady Murasaki, being herself a woman, naturally chose the medium of other women's minds. Aoi, Asagao, Fujitsubo, Murasaki, Yugao, Suyetsumuhana, the beautiful, the red-nosed, the cold, the passionate-one after another they turn their clear or freakish light upon the gay young man at the centre, who flies, who pursues, who laughs, who sorrows, but is always filled with the rush and bubble and chuckle of life" (267). Woolf proposed that all of the female characters in The Tale of Genji were depicted by Lady Murasaki as women who have their own characteristics and they used it to pursue the shining prince.

At the end, Woolf gave complements to Lady Murasaki as the author of The Tale of Genji. Wool states that "all comparisons between Murasaki and the great Western writers serve but to bring out her perfection and their force. But it is a beautiful world; the quiet lady with all her breeding, her insight and hre fun, is a perfect artist" (268). It seemed like Mrs. Woolf was really happy in reading The Tale of Genji through the English translation by Arthur Waley. According to the editor of Woolf's essay, 
Andrew McNeillie, "Woolf even invited Waley in a dinner to discuss about The Tale of Genji since Woolf was so interested to The Tale of Genji and could not understand Japanese as well as Waley" (268). Woolf's essay about The Tale of Genji really gave us example of how Westerns perceived The Tale of Genji through the English translation. So, we found out that the Westerns have good opinions on The Tale of Genji through English translations (in this case, Waley's translation).

\section{B. RQ 2: Why are The Tale of Genji's translations being accepted as world literature?}

\section{Translation}

The popularity of The Tale of Genji cannot be separated from the an essential role of translation. The Tale of Genji found its step to the way of popularity when Waley published his English translation of this novel in 1933. Waley also got advantages in translating The Tale of Genji. Fryer says that "Waley himselfalso achieved fame in Japan. The Japanese government invited him to Japan several times, and apart from countless studies of his Genji by Japanese scholars, a book-length biography of Waley has been published in Japanese, and his translation of The Tale of Genji has recently been retranslated into Japanese, the first volume of which was published in September 2008" (43). Particularly, the translation brings advantages for the translator and the translation. Regarding to the willingness in gaining advantages in translating literary works, the translators probably might deceive the original literary work to gratify the readers or make the translator's translation fit to the country's or readers' social constructs or expectation.

It is true that many scholars hesitate about the truth of the translations. They might think that a translation is not a original product and might lead the readers to the other interpretation that may lead to the failure in understanding the original literary product. But we cannot deny that translation is a main key in interpreting the multicultural expressions. Rose states that "translating always involves usurping the Other's voice, and the need to make multicultural expressions maximally available means that those other voices will necessarily be altered" (26). Rose also added that "what is always true in any translation project is that there is some kind of purpose behind it and that translators must accede to that purpose, which always includes some component of decision making for two Others-the source author and the target audience" (26). So, the translators might fulfill the purpose of voicing the Other through his translation.

Fryer notes about Waley's comments in Waley's own essay entitled 'Notes on Translation' that has been published in 1958. It states that Waley "discusses several principles that he adhered to in his own translations so that the readers of his translation can get what he intends to explain about Japanese literature through his translation, including: being faithful by avoiding literal translation; the occasional necessity of elaboration; using natural English for dialogue; the importance of rhythm; accuracy; and the choice of texts. In discussing these points, he compares passages from some published translations of Asian literature with his own versions, and in every case it is Waley that comes out on top" (43). Waley also tried to fulfill the purpose in translating The Tale of Genji by using important principles that he thought might be very useful to convey his ideas of Japanese literature to the readers of his translation.

\section{World Literature}

Moulton in Lawall (1996) proposed that "world literature - in addition to being a collection of global masterpieces-was also a proving-ground for literary theory, an indispensable part of cultural studies, and a fundamental course for nationwide extension programs" (3). So, world literature supposed to be the collection of global masterworks and also being the part in studying cultures. Damrosch (2003) 
defined world literature which focused on the world, the text, and the reader.

1. World literature is an elliptical refraction of national literatures.

2. World literature is writing that gains in translation.

3. World literature is not a set canon of texts but a mode of reading: a form of detached engagement with world beyond our own place and time. (281).

These three definitions of world literature by Damrosch may lead us to the analysis of whether The Tale of Genji can be proclaimed as world literature or not.

\section{The Tale of Genji as World Literature}

The three definitions that have been clarified above are suitable for The Tale of Genji. For the first, world literature is an elliptical refraction of national literatures. The same plot or theme which is in The Tale of Genji can be found in several countries. It means The Tale of Genji is an elliptical refraction of national literatures. For example, the Dream of Red Chamber/Mansion. A Dream of Red Mansions, which had been entitled as The Story of the Stone, was written in Qianlong period of Qing Dynasty. In 1784 (the 49th year by the rein of Emperor Qianlong), the edition edited by Master Mengjue officially renamed it as $A$ Dream of Red Mansions. "The Tale of Genji, and A Dream of Red Mansions are the classic work of oriental literature. The protagonists Murasaki-noue and Daiyu, as the representatives of eastern ideal female images, reflect the similarities and differences between Japanese culture and Chinese culture" (Zhou 25). Zhou also clarified that "The Tale of Genji and The Dream of Red Mansions often become the object of comparative studies because of their similarities in the main characters, the theme, or the plot of the story and regarding to the time of the publication, $A$
Dream of Red Mansion has been clarified to be influenced by The Tale of Genji since at that era, China was colonized by Japan" (24). It means The Tale of Genji fits the first definition of world literature where The Tale of Genji has become an elliptical refraction of national literatures.

The second definition is world literature is writing that gains in translation. The Tale of Genji also fits this definition since that novel have been translated into English by three Westerns (Waley-1933, Seidensticker-1977, and Tyler-2001).

The third definition is world literature is not a set canon of texts but a mode of reading: a form of detached engagement with world beyond our own place and time. Damrosch proposed that "the sequence of Genji translations indicates that more and more readers are indeed becoming ready for just this sort of contextual framing." The Tale of Genji caught the readers' attention and make the readers want to read it more and evaluate it more. That is why from time to time the translator tried to translate The Tale of Genji in a better way they thought so that the readers' enthusiasm in knowing Genji better can be fulfilled.

So, based on the explanations above, we found out that The Tale of Genji is suitable to be called world literature. Its translation is liked by the readers like what have been claimed by Woolf herself. This ancient novel also gains translations and became a novel which gained much of the translators' attention to translate it. This novel also has become the elliptical refraction for other cultures and nations. The readers are also very indeed on this novel.

\section{CONCLUSSION}

The findings that have been clarified above lead us to the conclusion that the Western perceived The Tale of Genji very well through the English translations that have been translated by several translators. Each translator might have his own strength and lack in 
translating The Tale of Genji, but the existences of the several English translations in The Tale of Genji showed the enthusiasm of the readers to know better about The Tale of Genji through the improvement of the English translations of the novel. The translation has become the media for people to know about the Japanese culture by reading The Tale of Genji and it made The Tale of Genji as the part of world literature since The Tale of Genji has the characteristics to be called world literature.

\section{REFERENCES}

Arntzen, Sonja. "The Heart of History: The Tale of Genji." Education about Asia 10 (2005): $25-30$

Askew, Rie Kido. "The Cultural Paradox of Modern Japan: Japan and Its Three Others." New Zealand Journal of Asian Studies 6 (2004): 130-149.

Damrosch, David. What is World Literature? New Jersey: Princeton University Press, 2003.

deGruchy, John Walter. Orienting Arthur Waley: Japonism, Orientalism, and the Creation of Japanese Literature in English. Honolulu: University of Hawaii Press, 2003.

Fryer, Bill. "In the Shadows of Waleyites: Authority, Creativity, and the Translation of Modern Japanese Poetry." Special Issue-2008 Rhizomes Conference 3 (2009): 40-50.

Ingram, Bryan. The Literature of Japan. New York: Henry Holt and Company, 1930.

Lawall, Sarah. "Richard Moulton and the Idea of World Literature." No Small World: Visions and Revisions of World Literature. Ed. Michael Thomas Carroll. New York: National Council of Teachers of English, 1996. 3-19.

Miyasaka, Natsumi Ikoma. Re-situating the Body: History, Myth, and the Contemporary Women's Writings in English and Japanese. Thesis. Durham University, 2002.

Murakami, Janel R. Goodman. "Metonymy in The Tale of Genji: An Analysis of Translation Strategies." Arizona Working Papers in SLA \& Teaching 20 (2013): 55-75.

Rose, Marilyn Gaddis Rose. "The Translator and the Voice of the Other: A Case in Point." No Small World: Visions and Revisions of World Literature. Ed. Michael Thomas Carroll. New York: National Council of Teachers of English, 1996. 20-33.

Said, Edward. Orientalism. London: Penguin, 1977.

Woolf, Virginia. The Essays of Virginia Woolf. New York: A Harvest Original Harcourt, Inc., (1925). 